\title{
A Compact High Pressure Ion Source for High and Low Energy Collision-induced Dissociation Studies of Cluster Ions on a VG Analytical ZAB-2FQ
}

\author{
J. E. Szulejko, C. E. C. A. Hop, and T. B. McMahon \\ Department of Chemistry and Guelph-Waterloo Centre for Graduate Work in Chemistry, University of \\ Waterloo, Waterloo, Ontario, Canada
}

A. G. Harrison and A. B. Young

Department of Chemistry, University of Toronto, Toronto, Ontario, Canada

\author{
J. A. Stone \\ Department of Chemistry, Queen's University, Kingston, Ontario, Canada
}

\begin{abstract}
A compact, field-free high pressure ion source designed to replace, with minimum disruption, the electron impact/chemical ionization ion source of a VG Analytical ZAB-2FQ hybrid $\mathrm{BEqQ}$ mass spectrometer is described. This ion source may be operated at temperatures from $\sim 40$ to $250{ }^{\circ} \mathrm{C}$ and at pressures up to $4-5$ torr and, thus, is capable of producing proton-bound cluster ions up to hexamers in good yields. Examples of high energy collision-induced dissociation, low energy collision-induced dissociation, and neutralization-reionization studies of proton-bound cluster ions produced in this source are presented. (] Am Soc Mass Spectrom 1992, 3, 33-38)
\end{abstract}

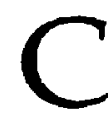

hemical ionization $(\mathrm{CI})$ is known to add significantly to the analytical capacity of mass spectrometry [1]. Cl mass spectra not only display a simpler fragmentation pattern than do electron impact (EI) mass spectra, but also they usually contain an ion characteristic of the molecular weight in relatively high abundance. At relatively high pressures ( $\geq 1$ torr) cluster ions can be generated efficiently as well. For example, Dawson [2] used atmospheric pressure chemical ionization to generate the protonbound hexamer of water, $\left(\mathrm{H}_{2} \mathrm{O}\right)_{6} \mathrm{H}^{+}$. However, our previous work [3] showed that standard (VG Analytical) $\mathrm{EI} / \mathrm{CI}$ ion sources are rather inefficient for generation of cluster ions such as proton-bound dimers. This can be ascribed to the rather high minimum ion source operating temperature, $180^{\circ} \mathrm{C}$, and the maximum ion source pressure of $\sim 0.2$ torr [4]. If the ion source filament was turned off for several hours, the ion source temperature could be as low as $30^{\circ} \mathrm{C}$, however, the temperature increased to $100{ }^{\circ} \mathrm{C}$ in $<30$ min once the filament was turned on. Consequently, the cluster ions of interest were intense at first, but

Address reprint requests to Alex G. Harrison, Department of Chemistry, Lash Miller Chemical Laboratories, University of Toronto Toronto, Ontario, Canada M5S 1A1. the signals decreased rapidly. The maximum ion source pressure of $\sim 0.2$ torr also limits the production of cluster ions. Despite these two factors, collision-induced dissociation (CID) mass spectra of cluster ions, such as the proton-bound acetone-dimethyl ether cluster [3] and proton-bound clusters of alkoxide ions [5] have been obtained. CID work on cluster ions has been reported earlier, but mainly has been limited to relatively small clusters [2, 6-10]. Unimolecular fragmentation of proton-bound dimers also has been used to generate a beam of fast neutral monomers to be ionized further downstream in the second field-free region of a VG Analytical ZAB-2F [11].

A compact high pressure ion source has been designed to fit in the existing ion source housing of the VG Analytical ZAB-2FQ hybrid BEqQ mass spectrometer in the Ontario Regional Ion Chemistry Laboratory at the University of Toronto. Because most other VG mass spectrometers have an ion source housing of similar design, this high pressure ion source has widespread applications. The electron gun is mounted in line with the ion beam axis, and the ion source is equipped with two skimmer cone lenses and a set of beam centering-focusing plates. The whole assembly is mounted on a $187-\mathrm{mm}$ O-ring flange which replaces the standard $\mathrm{ZAB}$ flange. The modifications to the 
standard $\mathrm{ZAB}-2 \mathrm{~F}$ ion source electronics have been kept to a minimum. Switching between the new high pressure source and the standard $\mathrm{EI} / \mathrm{CI}$ ion source requires only $15 \mathrm{~min}$. Earlier, van Koppen et al. [12] designed a high pressure source for their ZAB-2F but the size of the cluster ions was limited because the source pressure could not exceed 1 torr.

In this article we describe the design of the high pressure ion source in detail. High energy $(6-8 \mathrm{keV})$ and low energy (2-50 eV) CID mass spectra of a few selected examples are presented to illustrate the performance of the source. Neutralization-reionization (NR) mass spectra demonstrate that no loss of sensitivity is incurred by installation of the new source.

\section{Experimental}

The schematic of the ion source in relation to the $\mathrm{ZAB}$ ion source housing is shown in Figure 1. The source is designed to be as compact as possible to fit into the available space. Nevertheless, the EI/CI slit drive magnet and part of the lower guide dowel rod have to be removed for the installation of the high pressure source. Ease of use also requires a minimum number of modifications to the existing electronics because the standard EI/CI source still is used for other work on the instrument.

The electron gun is a two-thirds scale model of the ones used in the high pressure mass spectrometers of Kebarle [13b] and Szulejko et al. [3]. It is mounted coaxially with respect to the ion beam axis. The elec- tron gun is wrapped in metal foil to minimize the effect of the fringing field of the magnetic sector. Little electron gun retuning is required in going from low to high masses. The lens elements are constructed out of nonmagnetic stainless steel.

The stainless steel ion source block consists of two discs (64 $\mathrm{mm}$ in diameter, $6.4 \mathrm{~mm}$ thick) which sandwich a hollow cylinder (19 $\mathrm{mm}$ long, $13 \mathrm{~mm}$ internal, and $38 \mathrm{~mm}$ external diameter). This construction results in an ion source chamber, which is $13 \mathrm{~mm}$ in diameter and $19 \mathrm{~mm}$ long. The electron entrance and ion exit apertures are formed by nickel foils (electron microscope apertures) clamped to the inside of the two disks. The size of these apertures can be varied from $1.0 \mathrm{~mm}$ (no foil) to $0.10 \mathrm{~mm}$ by using nickel foils with different size apertures. The ion source block holds four cartridge heaters, which can provide stable $\left( \pm 1{ }^{\circ} \mathrm{C}\right.$ ) source temperatures up to $250^{\circ} \mathrm{C}$ (as measured by a thermocouple with monitoring by the $\mathrm{ZAB}$ source temperature readout). In the absence of heating the source temperature is $-40{ }^{\circ} \mathrm{C}$ with the instrument in operation. Samples are premixed in large stainless steel vessels or glass bulbs and bled into the ion source via a fine metering valve. A metal line leads into the ion source chamber half way along the cylinder wall. The ion source itself is isolated from ground by a 75-mm-long quartz capillary tube of 0.1 $\mathrm{mm}$ internal diameter in the gas lead. The ion source can be operated at $+8 \mathrm{kV}$ potential without discharges with this arrangement. At maximum ion source pressure, the source housing pressure, as mea-
Figure 1. Detailed drawing of the high pressure ion source. 1, flament and insulating support; 2, draw-out; 3. extractor: 4, 5, 6, Einzel lens; 7, 8, electron beam deflector plates in $x$ and $y$ directions; 9 , shielding tunnel; 10, gas inlet line containing $75-\mathrm{mm}$ length of $0.1-\mathrm{mm}$ quartz capillary tubing; 11, ion source block with ion exit and electron entrance apertures in $\mathrm{Ni}$ foils; 12 , source heaters (4); 13,14 cylindrically symmetrical electrodes; 15, focus and beam centring half plates; 16, adjustable source slit (ZAB); 17 , to $150 \mathrm{~mm}$; Diffstak pump; 18 , existing $\mathrm{ZAB}$ source housing; 19 . $O$-ring gasket; 20 , flange containing 24 electrical feed-throughs, gas-line feed-through and filament viewing port: 21 , viewing port in source housing.

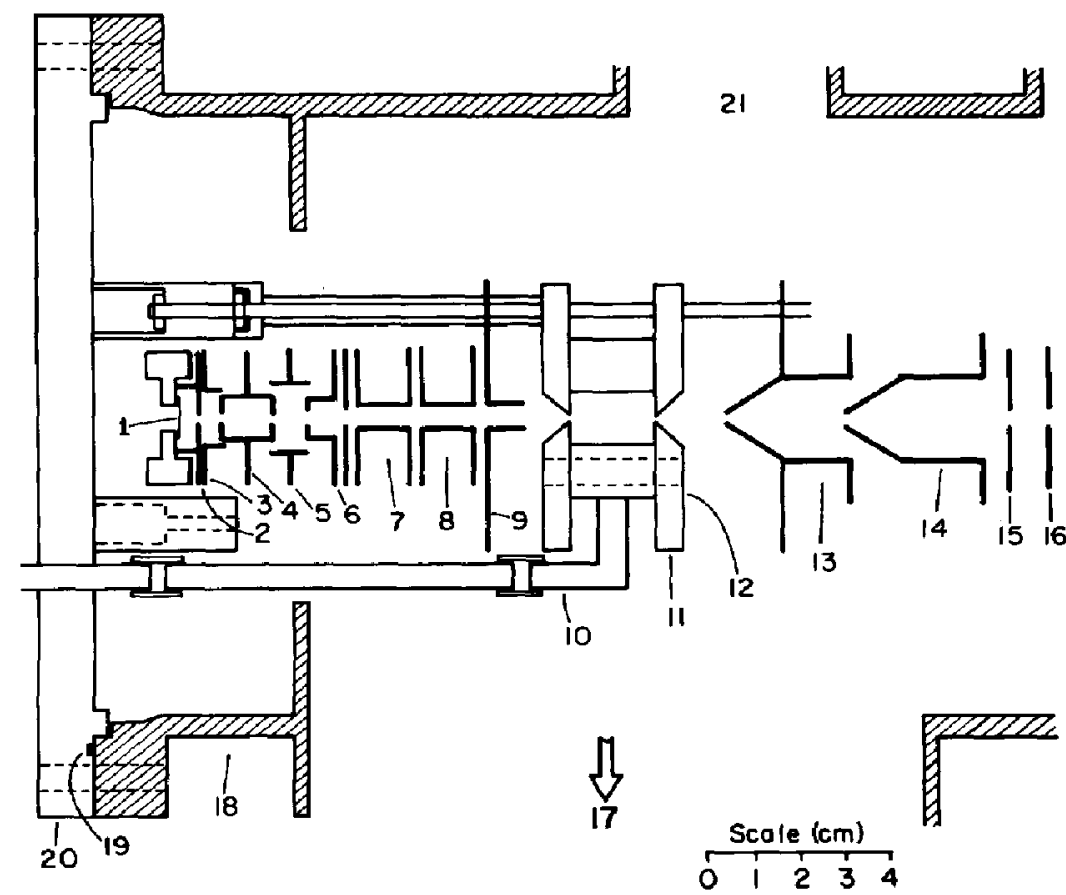


sured by an ion gauge located above an $800 \mathrm{~L} \mathrm{~s}^{-1} 150$ mm Edwards Diffstak diffusion pump, is $\sim 1 \times 10^{-4}$ torr. Under these conditions the pressure inside the ion source is $-4-5$ torr, as determined on a high pressure mass spectrometer at the University of Waterloo [3] with similarly sized apertures and pumping. The ion current at the collector in the third field-free region (after the electric sector) is comparable to that obtained in the $\mathrm{CI}$ mode of operation of the standard $\mathrm{ZAB}$ ion source.

Some extra electronics were necessary for the operation of the high pressure ion source. These consist of resistor chains for the potentials to the elements of the electron gun and the two skimmer cone lenses. The electron energy is supplied by a 3-kV Hewlett-Packard power supply floating at ion source potential (furnished by the standard $Z A B$ high voltage supply). The current for the electron gun filament is supplied by a $0-10 \mathrm{~A}, 0-50 \mathrm{~V}$ Hewlett-Packard current supply, which floats at the electron energy supply output. The electron energy high voltage unit supplies one end of a resistor chain, referenced to the ion source potential, for the lens elements of the electron gun. The potentials for the deflectors of the electron gun (two pairs, 7 and 8, orthogonally disposed) are provided by a pair of $100-\mathrm{V}$ dry cells floating at ion source potential. Once the electron gun has been tuned, the settings do not vary significantly from day to day. The $\mathrm{ZAB}$ beam centring/focus controls from the EI module are used as the supply for a pair of lens plates (15) just after the second cone and before the resolving slit (16). The standard $\mathrm{ZAB}$ electronics also are used for the ion source heaters, the thermocouple readout, and the high voltage for the ion source.

The standard features of the ZAB-2FQ hybrid BEqQ mass spectrometer have been described elsewhere [14]. Briefly, high energy CID experiments can be carried out by mass selecting the ion beam of interest with the magnetic sector, colliding the ions with a collision gas in a cell between the B and E sectors, and analyzing the products according to their kinetic energy by scanning the electric sector. Low energy CID experiments can be carried out by selecting the ion beam of interest with the double-focusing instrument, decelerating the ions to the required energy and colliding the ions with a collision gas in the radio frequency-only quadrupole cell with analysis of fragment ions by the final mass-analyzing quadrupole. The instrument is equipped with two collision cells and an intermediate deflector electrode in the field-free region between the $B$ and $E$ sectors permitting NR experiments as well.

The ions of interest were generated by $\mathrm{Cl}$ with $\mathrm{CH}_{4} . \mathrm{He}, \mathrm{N}_{2}$, and $\mathrm{O}_{2}$ were used as target gases in collision-induced experiments. In the NR experiments $\mathrm{NH}_{3}$ was used as the neutralization gas and $\mathrm{O}_{2}$ was the reionization target gas. The pressure of all target gases was such that the main ion beam intensity was reduced by $\sim 20-30 \%(80-70 \% \mathrm{~T})$.

\section{Results and Discussion}

With the standard $\mathrm{ZAB} \mathrm{CI}$ source the production of proton-bound clusters is usually limited to dimers formed in low yield. However, with the present high pressure source proton-bound trimers and tetramers are generated in abundance using the source at ambient temperature. The high pressure $(\sim 4$ torr) mass spectrum of $\mathrm{CH}_{4}$ containing traces of background water is presented in Table 1.

A commonly used procedure to obtain structural information is CID [15], which may be carried out either at high (6-8 keV) collision energies, where predominantly electronic excitation occurs in the collision event [16], or at low (2-100 eV) collision energies where primarily vibrational and rotational excitation of the ion occurs in the collision event [16]. The 6-keV CID mass spectrum of $\left(\mathrm{CH}_{3} \mathrm{COCH}_{3}\right)$ $\left(\mathrm{CD}_{3} \mathrm{COCD}_{3}\right)_{2} \mathrm{H}^{+}$is shown in Figure 2 and is dominated by $\mathrm{CH}_{3} \mathrm{COCH}_{3}$ and $\mathrm{CD}_{3} \mathrm{COCD}_{3}$ loss. It can be seen that there is an isotope effect in favor of loss of $\mathrm{CH}_{3} \mathrm{COCH}_{3}$ over $\mathrm{CD}_{3} \mathrm{COCD}_{3}$. This spectrum is the sum of 25 2-s scans and clearly gives a CID mass spectrum with an excellent signal-to-noise ratio of 500.

Addition of a small amount of water is enough to generate mixed acetone-water clusters. The 6-keV $\mathrm{CID}$ mass spectrum of $\left(\mathrm{CH}_{3} \mathrm{COCH}_{3}\right)\left(\mathrm{CD}_{3} \mathrm{COCD}_{3}\right)_{2}$ $\left(\mathrm{H}_{2} \mathrm{O}\right) \mathrm{H}^{+}$is shown in Figure 3a. Energy-resolved low energy CID data, using the quadrupole system, reveal that loss of $\mathrm{H}_{2} \mathrm{O}$ is the dissociative process of lowest energy requirement in agreement with the very recent metastable ion studies of Lifshitz and co-workers [17]. (Loss of $18 \mathrm{u}$ from $\left(\mathrm{CH}_{3} \mathrm{COCH}_{3}\right)_{3}\left(\mathrm{H}_{2} \mathrm{O}\right) \mathrm{H}^{+}$indicates a water molecule is lost collisionally and not a methyl radical.) It is interesting to note that this ion and $\left(\mathrm{CD}_{3} \mathrm{COCD}_{3}\right)_{3}\left(\mathrm{H}_{2} \mathrm{O}\right) \mathrm{H}^{+}$only lose $\mathrm{H}_{2} \mathrm{O}$ collisionally and not $\mathrm{HDO}$ or $\mathrm{D}_{2} \mathrm{O}$ showing that the original $\mathrm{H}_{2} \mathrm{O}$ molecule is lost. These results are in marked contrast with those obtained for the ammonia analogues. No loss of $\mathrm{NH}_{3}$ is observed in the $8 \mathrm{keV}$ CID mass spectrum of $\left(\mathrm{CH}_{3} \mathrm{COCH}_{3}\right)\left(\mathrm{CD}_{3} \mathrm{COCD}_{3}\right)_{2}\left(\mathrm{NH}_{3}\right) \mathrm{H}^{+}$

Table 1. High pressure ( -4 torr) mass spectrum of $\mathrm{CH}_{4}$ containing traces of background water

\begin{tabular}{cc}
\hline \multicolumn{1}{c}{ lon } & Relative intensity \\
\hline $\mathrm{CH}_{5}^{+}$ & 2 \\
$\mathrm{H}_{3} \mathrm{O}^{+}$ & 18 \\
$\mathrm{C}_{2} \mathrm{H}_{5}^{+}$ & 2 \\
$\mathrm{H}_{3} \mathrm{O}^{+}\left(\mathrm{CH}_{4}\right)$ & 0.7 \\
$\left(\mathrm{H}_{2} \mathrm{O}_{2} \mathrm{H}^{+}\right.$ & 12 \\
$\mathrm{C}_{3} \mathrm{H}_{5}^{+}$ & 2 \\
$\mathrm{C}_{3} \mathrm{H}_{7}^{+}$ & 2 \\
$\left(\mathrm{H}_{2} \mathrm{O}\right)_{3} \mathrm{H}^{+}$ & 18 \\
$\left(\mathrm{H}_{2} \mathrm{O}\right)_{4} \mathrm{H}^{+}$ & 100 \\
$\left(\mathrm{H}_{2} \mathrm{O}\right)_{5} \mathrm{H}^{+}$ & 26 \\
$\left(\mathrm{H}_{2} \mathrm{O}\right)_{6} \mathrm{H}^{+}$ & 0.8 \\
\hline
\end{tabular}


$\left(\mathrm{CH}_{2} \mathrm{COCH}_{2}\right)\left(\mathrm{CO}_{2}, \mathrm{COCD}\right)_{2} \mathrm{H}^{*}$

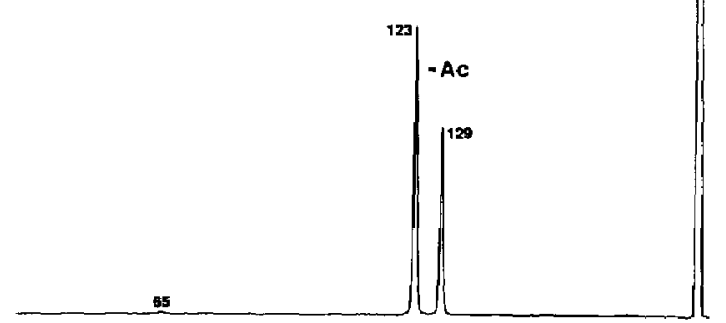

Figure 2. CID mass spectrum of a $6-\mathrm{keV}\left(\mathrm{CH}_{3} \mathrm{COCH}_{3}\right)$ $\left(\mathrm{CD}_{3} \mathrm{COCD}_{3}\right)_{2} \mathrm{H}^{+}$ions using $\mathrm{He}$ as target gas $(80 \% \mathrm{~T})$. Ac $=$ $\mathrm{CH}_{3} \mathrm{COCH}_{3}$ or $\mathrm{CD}_{3} \mathrm{COCD}_{3}$.

(see Figure $3 b$ ). This result is in agreement with the metastable ion studies of Castleman and co-workers [18] who observed only loss of acetone from such clusters. The difference in fragmentation behavior between the cluster ions containing $\mathrm{H}_{2} \mathrm{O}$ and those containing $\mathrm{NH}_{3}$ may be due to the fact that $\mathrm{NH}_{3}$ has a higher proton affinity than acetone (854 versus 823 $\mathrm{kJ} \mathrm{\textrm {mol } ^ { - 1 }}$ [19]), whereas $\mathrm{H}_{2} \mathrm{O}$ has a lower proton affinity than acetone (697 versus $823 \mathrm{~kJ} \mathrm{~mol}^{-1}$ [19]). Alternatively, a different structural orientation of the participating molecules in the cluster ions could be involved with a central $\mathrm{NH}_{4}^{+}$unit in $\left(\mathrm{CH}_{3} \mathrm{COCH}_{3}\right)$ $\left(\mathrm{CD}_{3} \mathrm{COCD}_{3}\right)_{2}\left(\mathrm{NH}_{3}\right) \mathrm{H}^{+}$and a peripheral $\mathrm{H}_{2} \mathrm{O}$ molecule in $\left(\mathrm{CH}_{3} \mathrm{COCH}_{3}\right)\left(\mathrm{CD}_{3} \mathrm{COCD}_{3}\right)_{2}\left(\mathrm{H}_{2} \mathrm{O}\right) \mathrm{H}^{+}$. As observed earlier, an isotope effect favors loss of

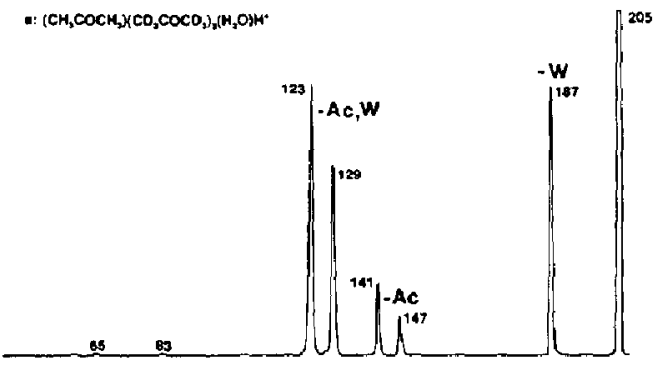

b: $\left(\mathrm{CH}_{3} \mathrm{COCH}_{3}\right)\left(\mathrm{CO}_{3} \mathrm{COCO}_{3}\right)_{3},\left(\mathrm{NH}_{3}\right) \mathrm{H}^{+}$

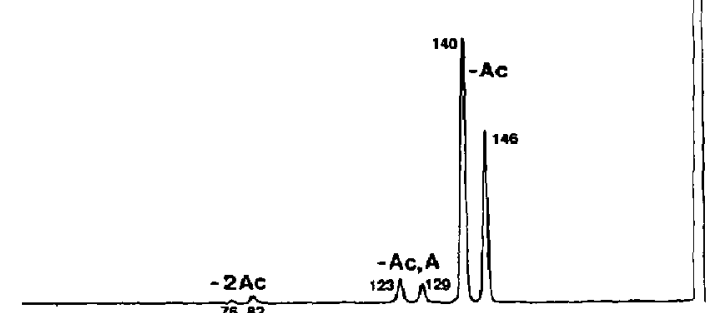

Figure 3. $\mathrm{CID}$ mass spectra of $6 \mathrm{keV}\left(\mathrm{CH}_{3} \mathrm{COCH}\right)_{3}$ $\left(\mathrm{CD}_{3} \mathrm{COCD}_{3}\right)_{2}\left(\mathrm{H}_{2} \mathrm{O}\right) \mathrm{H}^{+}$ions (a) and $\left(\mathrm{CH}_{3} \mathrm{COCH}_{3}\right)$ $\left(\mathrm{CD}_{3} \mathrm{COCD}_{3}\right)_{2}\left(\mathrm{NH}_{3}\right) \mathrm{H}^{+}$ions (b) using He as target gas $(80 \% \mathrm{~m})$. $\mathrm{Ac}=\mathrm{CH}_{3} \mathrm{COCH}_{3}$ or $\mathrm{CD}_{3} \mathrm{COCD}_{3} ; \mathrm{W}=\mathrm{H}_{2} \mathrm{O}$; and $\mathrm{A}=\mathrm{NH}_{3}$.
$\mathrm{CH}_{3} \mathrm{COCH}_{3}$ over $\mathrm{CD}_{3} \mathrm{COCD}_{3}$. This isotope effect will be discussed in detail elsewhere [20].

The high degree of clustering attainable in this high pressure source is probably best illustrated by the observation of $\left(\mathrm{CH}_{3} \mathrm{COCH}_{3}\right)_{4}\left(\mathrm{NH}_{3}\right) \mathrm{H}^{+}$and $\left(\mathrm{CH}_{3} \mathrm{COCH}_{3}\right)_{5}\left(\mathrm{NH}_{3}\right) \mathrm{H}^{+}$. The high abundance of cluster ions arises not only because of the pressures obtainable but also with $0.15-\mathrm{mm}$ electron entrance and ion exit orifices the source is field-free and the ions have a long source residence time before diffusing out of the source. Absence of loss of $\mathrm{NH}_{3}$ upon collisional activation of these large cluster ions is in keeping with the results for $\left(\mathrm{CH}_{3} \mathrm{COCH}_{3}\right)\left(\mathrm{CD}_{3} \mathrm{COCD}_{3}\right)_{2}\left(\mathrm{NH}_{3}\right) \mathrm{H}^{+}$.

The third quadrupole stage of the $\mathrm{BEqQ}$ instrument provides the opportunity to study the fragmentation of cluster ions at variable, low collision energies. This permits the derivation of breakdown graphs (fractional ion intensities versus collision energy) expressing, at least qualitatively, the energy dependence of the fragmentation of the cluster ions [21]. Two examples are shown in Figures 4 and 5. These cluster ions were produced in high pressure $(\sim 4$ torr) $\mathrm{CH}_{4}$ which contained background water and to which a small amount of $\mathrm{CH}_{3} \mathrm{OH}$ had been added. The lowest energy fragmentation channel for the $\left(\mathrm{CH}_{3} \mathrm{OH}\right)_{3}\left(\mathrm{H}_{2} \mathrm{O}\right) \mathrm{H}^{+}$cluster is (Figure 4) elimination of $\mathrm{H}_{2} \mathrm{O}$. With increasing collision energy loss of $\mathrm{H}_{2} \mathrm{O}$ $+\mathrm{CH}_{3} \mathrm{OH}$ is observed and only low intensity ion signals are observed for fragment ions containing $\mathrm{H}_{2} \mathrm{O}$. These results are incompatible with a structure consisting of a central hydronium ion solvated by three methanol molecules. Rather the structure would appear to be a "linear" hydrogen-bonded structure with a terminal water which is readily lost on colli-

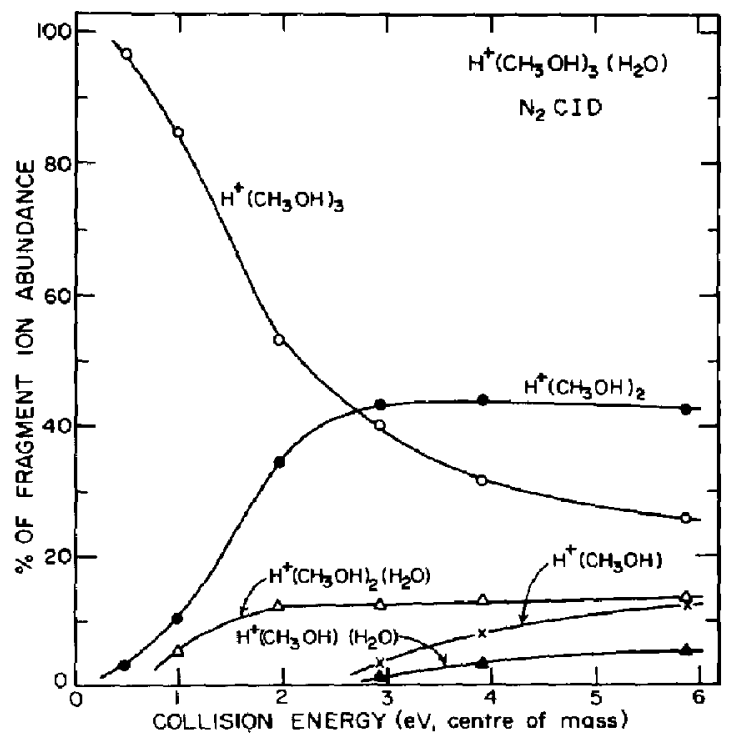

Figure 4. Breakdown graph for $\left(\mathrm{CH}_{3} \mathrm{OH}\right)_{3}\left(\mathrm{H}_{2} \mathrm{O}\right) \mathrm{H}^{+}, \mathrm{N}_{2}$ collision gas, $70 \% \mathrm{~T}$. 


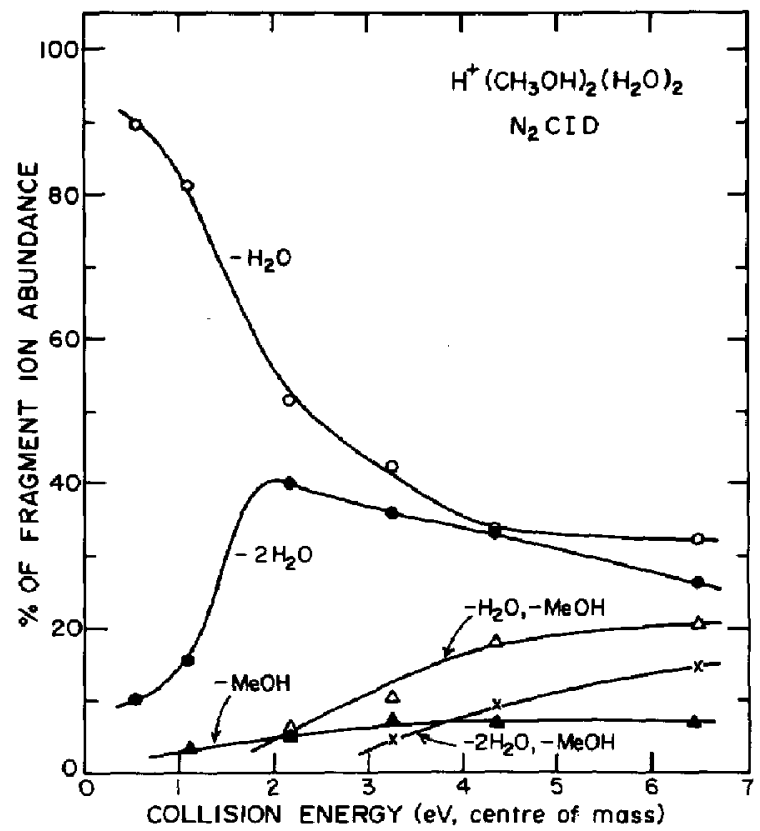

Figure 5. Breakdown graph for $\left(\mathrm{CH}_{3} \mathrm{OH}\right)_{2}\left(\mathrm{H}_{2} \mathrm{O}\right)_{2} \mathrm{H}^{+}, \mathrm{N}_{2}$ collision gas, $70 \% \mathrm{~T}$.

sional activation. Similar results and conclusions have been reported by Graul and Squires [9b]. Similarly, the ready loss of two molecules of water from the $\left(\mathrm{CH}_{3} \mathrm{OH}\right)_{2}\left(\mathrm{H}_{2} \mathrm{O}\right)_{2} \mathrm{H}^{+}$cluster (Figure 5) also suggests a "linear" structure for this proton-bound cluster ion. In both Figures 4 and 5, fragment ions are observed at - $0.5 \mathrm{eV}$ center-of-mass collision energy, i.e., at energies below the bond strength of $\sim 1 \mathrm{eV}$ in the complex. Clearly there are at least a few cluster ions which have not been thermalized; however, the plots do not reveal that the total fragment ion signal is quite small near the threshold and increases with increasing collision energy.

That no loss of sensitivity is incurred by installation of this high pressure source is illustrated by the ability to record neutralization-reionization mass spectra [22] of cluster ions. In such experiments at moderate collision target gas pressures $(-80 \%$ transmission of the main ion beam per collision gas) not more than $-0.2 \%$ of the mass selected ion beam is neutralized and reionized in the second freld-free region of $\mathrm{ZZAB}$ [22c, 23]. The NR mass spectrum of $\left(\mathrm{CH}_{3} \mathrm{COCH}_{3}\right)$ $\left(\mathrm{CD}_{3} \mathrm{COCD}_{3}\right) \mathrm{H}^{+}$is shown in Figure 6. This spectrum was obtained in about $15 \mathrm{~min}$ and is the summation of 100 separate scans. No recovery signal is present at $m / z 123$, indicating that the neutral $\left(\mathrm{CH}_{3} \mathrm{COCH}_{3}\right)$ $\left(\mathrm{CD}_{3} \mathrm{COCD}_{3}\right) \mathrm{H}$ is not stable under the present experimental conditions; it fragments into acetone $(\mathrm{m} / \mathrm{z} 58$ and 64) and [acetone $+\mathrm{H}](m / z 59$ and 65). Acetone molecules can be generated by $\mathrm{CID}$ of $\left(\mathrm{CH}_{3} \mathrm{COCH}_{3}\right)$ $\left(\mathrm{CD}_{3} \mathrm{COCD}_{3}\right) \mathrm{H}^{+}$upon interaction with the neutraliza-

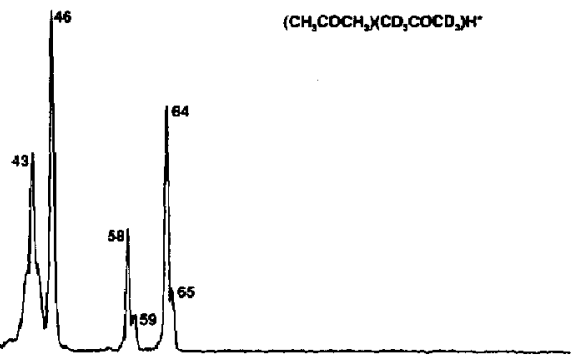

Figure 6. NR mass spectrum of $8-\mathrm{keV}\left(\mathrm{CH}_{3} \mathrm{COCH}_{3}\right)$ $\left(\mathrm{CD}_{3} \mathrm{COCD}_{3}\right) \mathrm{H}^{+}$ions using $\mathrm{NH}_{3}$ for neutralization and $\mathrm{O}_{2}$ for reionization ( $80 \% \mathrm{~T}$ for both gases).

tion target gas, $\mathrm{NH}_{3}$, as well. However, the contribution from this process must be limited since $\mathrm{m} / z$ 65 is considerably more intense than $m / z 59$ in the CID mass spectrum of $\left(\mathrm{CH}_{3} \mathrm{COCH}_{3}\right)\left(\mathrm{CD}_{3} \mathrm{COCD}_{3}\right) \mathrm{H}^{+}$; i.e., loss of $\mathrm{CH}_{3} \mathrm{COCH}_{3}$ occurs much more readily than loss of $\mathrm{CD}_{3} \mathrm{COCD}_{3}$. The acetyl ions, $\mathrm{CH}_{3} \mathrm{CO}^{+}$and $\mathrm{CD}_{3} \mathrm{CO}^{+}$, are generated by fragmentation of ionized acetone. The isotope effect ( $m / z 64$ and 65 are much more intense than $m / z 58$ and 59) is surprisingly large and will be explained elsewhere [20].

\section{Conclusions}

The design of a simple high pressure source for a VG Analytical ZAB mass spectrometer has been described in detail. The results show that a significantly higher degree of clustering can be obtained with this source than with the standard $\mathrm{ZAB} \mathrm{Cl}$ source. Species as complex as $\left(\mathrm{CH}_{3} \mathrm{COCH}_{3}\right)_{5}\left(\mathrm{NH}_{3}\right) \mathrm{H}^{+}$and $\left(\mathrm{CH}_{3} \mathrm{OH}\right)_{6} \mathrm{H}^{+}$have been observed. Using the standard features of the University of Toronto ZAB-2FQ both low and high energy CID mass spectra of cluster ions can be recorded. For cluster ions which are generated abundantly in the ion source NR mass spectra also can be obtained. More work is in progress regarding the gas-phase ion chemistry of many compounds in a high pressure environment. In addition, the ion source will be modified so that negatively charged cluster ions can be studied as well.

\section{Acknowledgments}

Drs. Harrison, Stone, and McMahon thank the Natural Sciences and Engineering Council of Canada (NSERC) for financial support. Dr. McMahon also acknowledges financial support from the Ontario Ministry of the Environment and the Petroleum Research Fund administered by the American Chemical Society.

\section{References}

1. (a) Harrison, A. G. Chemical Ionization Mass Spectrometry, CRC Press: Boca Raton, FL, 1983. (b) Budzikiewicz, H. Mass Spectrom. Rev. 1986, 5, 345. (c) Harrison, A. G. Ado. Mass Spectrom. 1989, 11, 582.

2. Dawson, P. H. Int. J. Mass Spectrom. Ion Phys. 1982, 43, 195. 
3. Szulejko, J. E.; Fisher, J. J.; McMahon, T. B.; Wronka, J. Int. J. Mass Spectrom. Ion Processes 1988, 83, 147.

4. (a) Hancock, R. A.; Walder, R.; Weigel, H. Org. Mass Spectrom. 1979, 14, 507. (b) Szulejko, J. E. Ph.D. Thesis, University of Wales, Cardiff, 1981.

5. Haas, M. J. M.Sc. Thesis, University of Toronto, Toronto, 1990.

6. (a) Sunner, J.; Kebarle, P. J. Phys. Chem. 1981, 85, 327. (b) Lau, Y. K.; Ikuta, S.; Kebarle, P. J. Am. Chem. Soc. 1982, $104,1462$.

7. (a) McLuckey, S. A.; Cameron, D.; Cooks, R. G. J. Am. Chem. Soc. 1981, 103, 1313. (b) Wright, L. G.; McLuckey. S. A.; Cooks, R. G.; Wood, K. V. Int. J. Mass Spectrom. Ion Phys. 1982, 42, 115. (c) McLuckey, S. A. Org. Mass Spectrom. 1984, 19, 545 .

8. Burnier, R. C.; Cody, R. B; Freiser, B. S, J. Am. Chem. Soc. 1982, 104,7436 .

9. (a) Graul, S. T.; Squires, R. R. Int. J. Mass Spectrom. Ion Processes 1987, 81, 183. (b) Graul, S. T.; Squires, R. R. Int. J. Mass Spectrom. Ion Processes 1989, 84, 41. (c) Marinelli, P. J.: Squires, R. R. J. Am. Chem. Soc. 1989, 111, 4101. (d) Graul, S. T.; Brickhouse, M. D.; Squires, R. R. I. Am. Chem. Soc. $1990,112,631$

10. Magnera, T. F.; David, D. E.; Stulik, D.; Orth, R. G.; Jonkman, H. T.; Mich1, J. I. Am. Chem. Soc. 1989, 111, 5036.

11. (a) Holmes, J. L.; Mommers, A. A.; Terlouw, I. K.; Hop, C. E. C. A. Int. J. Mass Spectrom. Ion Processes 1986, 68, 249. (b) Burgers, P. C.; Holmes, J. A.; Hop, C. E. C. A.; Terlouw, J. K. Org. Mass Spectrom. 1986, 21, 105.

12. van Koppen, P. A.; Kemper, P. R.; Illies, A. J.; Bowers, M. T. Int. I. Mass Spectrom. Ion Processes 1983, 54, 263.

13. (a) Cunningham, A. J.; Payzant, J. D.; Kebarle, P. J. Am Chem. Soc. 1972, 94, 7627. (b) Kebarle, P. In Techniques for the Study of Ion-Molecule Reactions; Farrar, J. M, and Saunders, W. H. Jr., Eds.; Wiley: New York, 1988; pp. 221-286.
14. Harrison, A. G.; Mercer, R. S.; Reiner, E. J.; Young, A. B.; Boyd, R. K.; March, R. E.; Porter, C. J. Int. J. Mass Spectrom. Ion Processes 1986, 74, 13.

15. (a) Holmes, J. L. Org. Mass Spectrom. 1985, 20, 169. (b) Busch, K, L.; Glish, G. L.; McLuckey, S, A. Mass Spectrometry/Mass Spectrometry: Techniques and Applications of Tandern Mass Spectrometry, VCH: New York, 1988. (c) Bordas-Nagy, J.; Jennings, K. R. Int. I. Mass Spectrom. Ion Processes 1990, $100,105$.

16. (a) Refaey, K. M.; Chupka, W. A. J. Chem. Phys. 1965, 43. 2544. (b) Yamaoka, H.; Dong, P.; Durup, J. J. Chem. Phys. 1969, 51, 3465.

17. Aviyente, V.; Iraqi, M.; Peres, T.; Lifshitz, C. J. Am. Soc. Mass Spectrom. 1991, 2, 113.

18. Tzeng, W. B.; Wei, S.; Castleman, A. W., Jr. Chem. Phys. Lett. 1990, 166, 3434

19. Lias, S. G.; Bartmess, J. E.; Liebman, J. F.; Holmes, J. L.; Levin, R. D.; Mallard, W. G. J. Phys. Chem. Ref. Data 1988, 17. Suppl. 1.

20. Szulejko, J. E.; Hop, C. E. C. A.; McMahon, T. B. Work in progress.

21. (a) McLuckey, S. A.; Glish, G. L.; Cooks, R. G. Int. J. Mass Spectrom. Ion Phys. 1981, 39, 219. (b) Fetterolf, D. D.; Yost, R. A. Int. J. Mass Spectrom. Ion Phys, 1982, 44, 37. (c) McLuckey, S. A.; Cooks, R. G. In Tandem Mass Spectrometry; McLafferty, F. W., Ed,; Wiley: New York, 1983; pp. 303-320.

22. (a) Wesdemiotis, C.; McLafferty, F. W. Chem. Rev. 1987, 87, 485. (b) Terlouw, J. K.; Schwarz, H. Angew. Chem. Int. Ed. Engl. 1987, 26, 805. (c) Hop, C. E. C. A. Ph.D. Thesis, University of Uttecht, Utrecht, 1988. (d) Holmes, J. L. Mass Spectrom. Rev. 1989, 8, 513. (e) McLafferty, F. W. Science 1990, 247, 925.

23. Hop. C. E. C. A.; Holmes, J. L. Org. Mass Spectrom. 1991, 26,476 